\title{
FeATURE Birds Point-New Madrid Floodway: Redesign, reconstruction, and restoration
}

\author{
Lois Wright Morton and Kenneth R. Olson
}

$\mathrm{T}$ he year 2011 was one of extreme weather, with 14 events in the United States causing losses in excess of one billion dollars each (Coumou and Rahmstorf 2012). The southeast Missouri region adjacent to the Lower Mississippi River well illustrates the local impacts on agriculture and human settlements when early snow melt and record rainfall over the Ohio River Valley and lands in the Lower Mississippi River result in saturated soils, extreme flooding, and damage to crop production and community infrastructure (Olson and Morton 2012a; 2012b). The May 2011 deliberate breaching of the levees in the New Madrid Floodway, Missouri, was a planned adaptation response to exceptional flooding conditions with the goal to reduce excess river pressure and prevent levee failures along the Ohio and Mississippi rivers (Camillo 2012). Climate scientists observe that 2011 was not unique, finding that the last decade was likely the warmest globally for at least a millennium, triggering a period of precipitation and heat wave extremes (Coumou and Rahmstorf 2012). As long-term weather patterns become more variable and unpredictable, there is much that can be learned from reevaluating past adaptation strategies and the exploration of new alternatives.

\section{LAND USE CHANGES}

The southeast Missouri region adjacent to the Lower Mississippi River, aka the Bootheel, was originally alluvial lowlands covered with swamps and old-growth forests historically exposed to seasonal flooding. Congressional authorization on September 30, 1850, to survey the Lower Mississippi River from Cairo, Illinois, to the Gulf of Mexico to address navigation and flooding problems was the precursor

Lois Wright Morton is professor of sociology in the College of Agriculture and Life Sciences, lowa State University, Ames, lowa. Kenneth R. Olson is professor of soil science in the College of Agricultural, Consumer, and Environmental Sciences, University of Illinois, Urbana, Illinois. to the construction of levees, dredging, and channelization which transformed the Bootheel into rich farmland (Barry 1997; Gellman and Roll 2011). Following World War I, many landowners and sharecroppers switched to cotton when wheat and corn prices crashed (Gellman and Roll 2011). In the early 1920s, as landowners doubled their cotton acreages, a large number of experienced cotton growers, including more than 15,000 sharecroppers from Tennessee, Louisiana, Arkansas, and Mississippi, were recruited to the floodway region. These sharecropping families typically contracted for a plot of land and in return received housing and half of the crop from the owner (Gellman and Roll 2011).

The US Army Corps of Engineers (USACE) had completed by 1926 the construction of levees on both sides of the Mississippi River between New Orleans, Louisiana, and Cairo, Illinois, including the Bootheel area of Missouri. After a winter and spring of heavy rains, on April 16, 1927, the Mississippi River at flood stage eroded the levee near Dorena, Missouri, resulting in a $364 \mathrm{~m}$ (1,200 ft) hole (Barry 1997). The levee breach, located $45 \mathrm{~km}$ (30 miles) south of Cairo, Illinois, flooded more than 70,000 ha $(175,000 \mathrm{ac})$. In all, the 1927 Lower Mississippi River flooding displaced more than 31,000 people in the Bootheel, mostly poor tenant farmers who suffered irreparable economic disaster and had to find new communities to resettle (Gellman and Roll 2011).

The Birds Point-New Madrid Floodway was built as a federal response to the Great Flood of 1927 (Barry 1997) that flooded millions of hectares (millions of acres) of rural and urban areas and led to the loss of thousands of lives. The creation of the floodway between 1928 and 1932 was to reduce future flooding pressures on cities with or without levees along the Ohio and Mississippi rivers (Olson and Morton 2012a). All of the land selected for the floodway was bottomland in Missouri, with most in agricultural use and only a few small towns, villages, con- servation areas, and scattered farmsteads. The USACE obtained easements with the help of eminent domain from all floodway landowners giving the USACE the right to pass floodwater into and through the Birds Point-New Madrid Floodway once the frontline levee was topped and to temporarily store floodwater in the basin.

The entire floodway was flooded once in 1937 after it was created. The USACE operational plan called for $17 \mathrm{~km}(11 \mathrm{mi})$ of the upper fuse plug area to be deliberately degraded by 0.9 to $1.6 \mathrm{~m} \mathrm{(3} \mathrm{to} 5 \mathrm{ft})$ to correspond to a flood stage reading of $16.7 \mathrm{~m}$ (55 ft) on the Cairo gage (Camillo 2012). A judge's ruling delayed the USACE from acting on this plan. As a result, the Cairo gage continued to rise, placing extreme pressure on the levee system. Crews were sent to Birds Point levee to dig trenches through the levee and induce failure, but that effort failed (Camillo 2012; Olson and Morton 2013). Finally, trinitrotoluene (TNT) was used for the first time to breach the Birds Point levee in four places; subsequently, the Mississippi River widened these breaches, quickly dropping the water level on the Cairo flood gage. Despite the redesign of the levee system to reduce water pressure on Ohio River and Mississippi River cities (Olson and Morton 2012a) and prevent another disaster, homes and fields of several thousand sharecroppers in the Bootheel region were flooded (Gellman and Roll 2011). These floods and the creation of the floodway resulted in many homeowners and sharecroppers moving from the villages, farmsteads, and sharecropper camps to bottomlands outside the floodway or to the higher adjacent uplands. Some who moved only repaired barns, sheds, and other structures necessary to support farming their land, while others repaired or replaced their homes and continued to live and work in the floodway after 1937.

As the years passed with no federal use of the floodway to divert Lower Mississippi River floodwaters, some landowners assumed there would never be another flood and went ahead with building and creating urban expansion plans on the bottom- 
lands (Lowery et al. 2009). The operation of the floodway and additional modifications were authorized by the 1965 Flood Control Act and included use of fuse plugs and opening with TNT. A revised operational plan in 1986 included exploding the fuse plugs at Birds Point, New Madrid, and the frontline levee near Big Oak Tree State Park. Floodway landowners sued the USACE (Story vs. Marsh case), and eventually the United States Court of Appeals for the Eighth Circuit sided with the USACE and reaffirmed their authority to operate the floodway (Olson and Morton 2012b).

In April of 2011, as floodwaters from the Ohio and Upper Mississippi rivers threatened to top and break through levee systems at Cairo and downstream, the Missouri Attorney General appealed to the Federal Courts, on behalf of the Missouri citizens and their properties including those in the floodway, in an attempt to block the USACE from opening the floodway. That Missouri appeal was rejected by the Supreme Court on May 1, 2011, and left standing the existing authority of the USACE to operate and open the floodway once a peak flow of greater than $18.3 \mathrm{~m}(60.5 \mathrm{ft})$ was forecast on the Cairo flood gauge.

The May 2, 2011, induced breach at Birds Point levee, the first explosion site, and the flooding of the New Madrid Floodway resulted in evacuation of homes and businesses but no loss of life. However, there was severe damage to most of the 80 homes (figure 1), a few churches, and 120 other barns (figure 2) and shed structures that were impacted by the force of flowing water and the 1.8 to $3 \mathrm{~m}$ (6 to $10 \mathrm{ft}$ ) of temporarily stored water (Schick 2011a). Water pressure caused loss of the lower half of walls, damaged most wooden floors, and in over 100 cases completely destroyed structures. Only a couple home sites were raised with soil and sand by approximately $3 \mathrm{~m}$ (10 ft) (figure 3) by the end of 2012. The local roads and bridges sustained considerable damage from the floodwaters. The Mississippi County transportation department requested US\$75 million from the USACE to repair the roads and bridges. That request was denied in July of 2012. However, another request for funds was submitted in 2012 to repair the roads damaged by the heavy trucks used to haul soil

\section{Figure 1}

One of the 80 homes in the floodway damaged by the 1.8 to $3 \mathrm{~m}$ of floodwater.

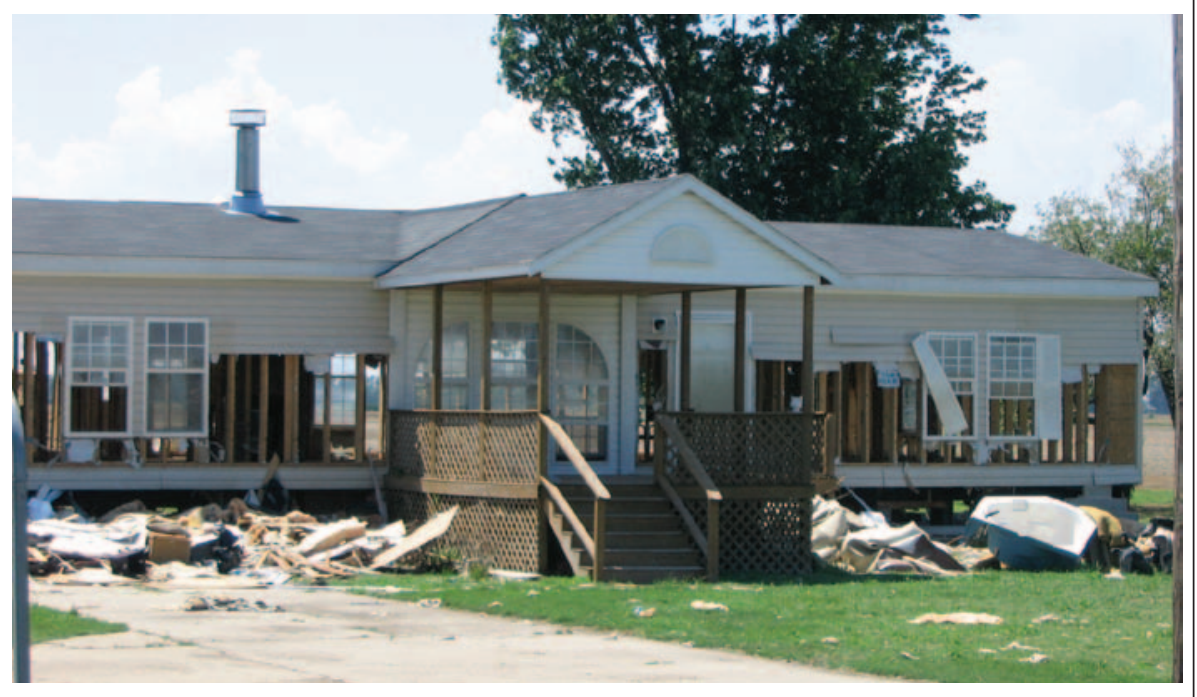

\section{Figure 2}

Farm structures, including a hog confinement facility, were damaged by the floodwaters and wind.

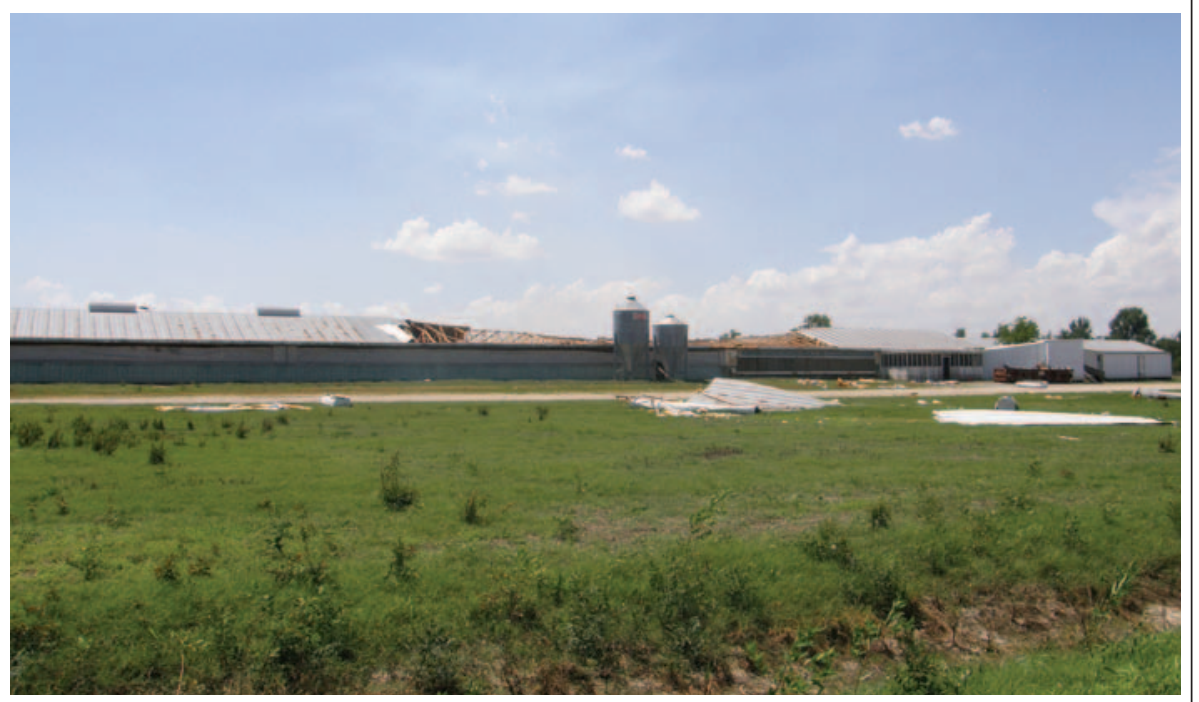

materials to patch the levee and fill in the crater lakes.

\section{THE VILLAGE OF PINHOOK, MISSOURI}

Much of the Missouri Bootheel region, including lands around the present day village of Pinhook in the center of the floodway (figure 4), was settled by sharecroppers in 1940s seeking to earn enough money from farming and off-farm work to purchase their own piece of land. In 1943, a plot of land west of Pinhook ridge freshly cleared of trees by local timber companies was sold at a very low price to five sharecroppers (Schick 2011a). Although the floodway was not put into use between 1937 and 2011, there was frequent annual local flooding within the New Madrid Floodway. Families who settled in Pinhook on the lower elevation lands west of Pinhook ridge experienced annual local flooding events. Platted in 1960s by Mississippi County, the homes on Pinhook ridge were about $1 \mathrm{~m}$ (3.3 ft) higher than the low lands, enough to avoid local flooding. However, when low lying areas flooded, residents used tractors and wagons to drive through the flooded areas to leave Pinhook ridge or get children to the school bus on the other side of the setback levee. At the time of the 2011 Flood 
and floodway opening, the community had 30 residents living on the slightly higher Pinhook ridge.

Although Pinhook is protected by the frontline levee, localized flooding occurs when water backs in from the Mississippi River northeast of New Madrid and through the nearby drainage ditch near Ten Mile Pond Conservation Area (figure $5)$. When the floodway setback levee was built between 1928 and 1932, a $455 \mathrm{~m}$ $(1,500 \mathrm{ft})$ gap was left as a drainage outlet or gap for runoff water from more than $45,000 \mathrm{ha}(112,500 \mathrm{ac})$ of lands within the floodway (Olson and Morton 2013). In 1954, the USACE gained approval to fill the gap and prevent the backwater flooding that threatened Pinhook almost every year (Schick 2011a). The proposed US $\$ 107$ million project to close the gap sat pending for decades, with its funding as a point of contention. At that time, Pinhook residents, with a median income of about US $\$ 15,000$ a year, were asked to pay $35 \%$ of the cost. In 1993 , the local share was reduced to $5 \%$, but another decade passed with no action. A leader of the village of Pinhook testified before Congress about the living conditions, and in 2003, the work to fill in the $455 \mathrm{~m}$ levee gap started. In 2004, the work stopped when the Environmental Defense Fund and National Wildlife Federation sued over its impact on wetlands. In 2004, a federal judge ordered an injunction to stop work on the levee and ordered the restoration of the area to its previous condition. Nearly US $\$ 7$ million had been spent to fill the levee gap, and US $\$ 10$ million was spent undoing the work (Schick 2011b). By 2005 , the levee gap and main drainage system were restored to 2002 conditions with no change in the local flooding situation.

In 2011 and 2012, the residents of Pinhook searched for land and money to relocate together outside the floodway. Assessment of the village of Pinhook by the Federal Emergency Management Association (FEMA) determined nearly every home's damage to be greater than $50 \%$ of its value. Consequently, the Pinhook residents would have to elevate their homes on stilts if they wanted to legally rebuild there. FEMA offered up to US $\$ 30,000$ to each homeowner for these repairs. Pinhook residents, many of them senior citizens, have not accepted those

\section{Figure 3}

One of the new homes being built on $3 \mathrm{~m}$ of soil materials.

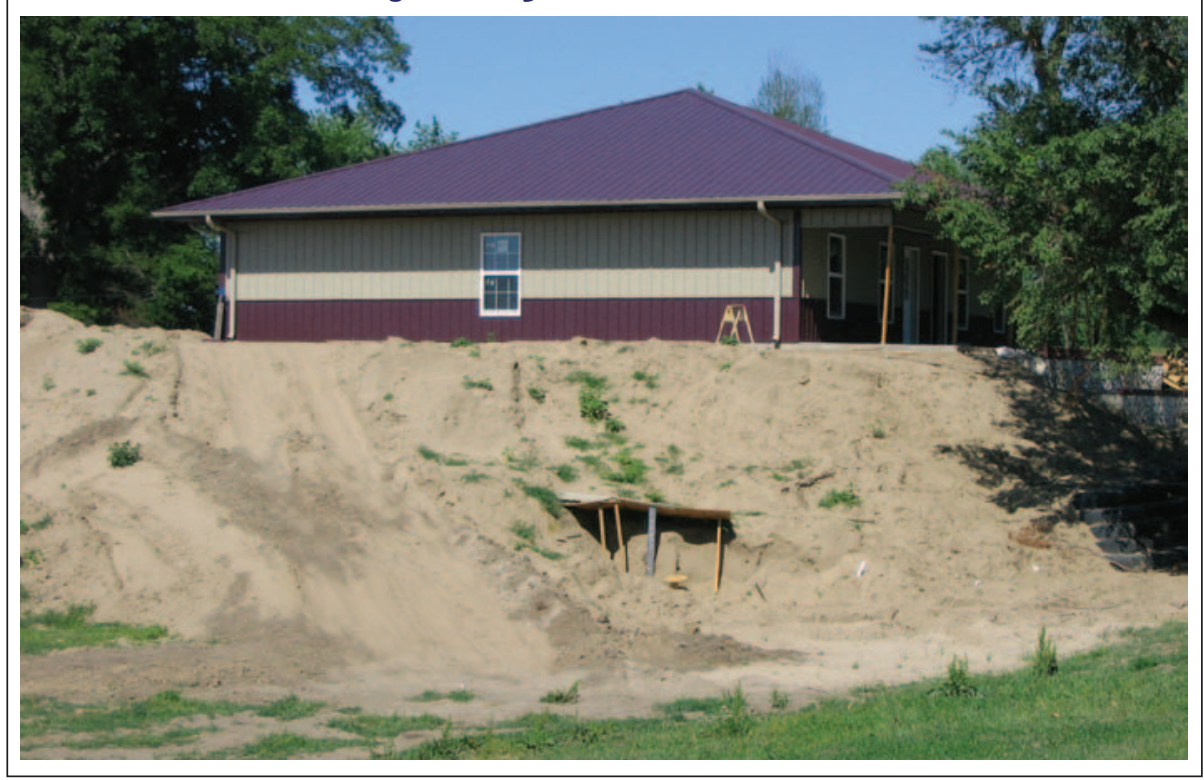

\section{Figure 4}

The village of Pinhook in November of 2011 after the homes were damaged by the 1.8 to $3 \mathrm{~m}$ of floodwater and abandoned.

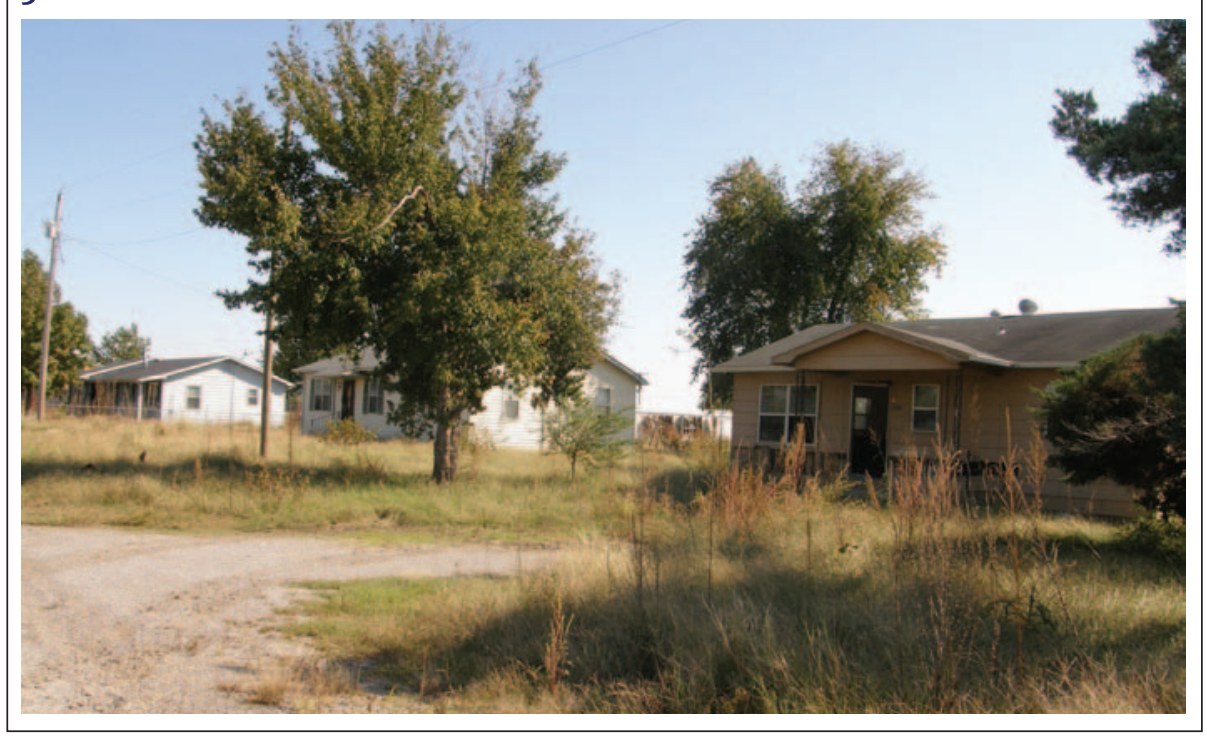

conditions. Most homeowners in Pinhook had home insurance but not flood insurance (Moyers 2011a). A FEMA buyout was accepted by owners of 21 properties (figure 4) and totaled US $\$ 1.17$ million, according to the Bootheel Regional Planning and Economic Development Commission.

\section{CHANGING LONG-TERM WEATHER PATTERNS}

Extreme events such as the 2011 flooding along the Mississippi River illustrate the challenges ahead for agriculture and communities of rural America as public agencies such as the USACE attempt to anticipate risk and manage emergency and evolving natural disasters related to water resources. The USACE's 2010 National Report acknowledges the increasing frequency and severity of extreme weather events and identifies climate change as a key variable. While the average annual local temperature in the Bootheel has decreased slightly from 1951 to 2010 (Benning et al. 2012), average temperatures in the Upper Great Lakes region are expected to increase by $2^{\circ} \mathrm{C}$ to $4^{\circ} \mathrm{C}$, with a $25 \%$ increase in precipitation by the end of the century (USACE 


\section{Figure 5}

Map of the Birds Point-New Madrid Floodway located in Missouri, just south of Cairo, Illinois. The location of the proposed wetlands, park land, and levee are shown.

\section{Legend}

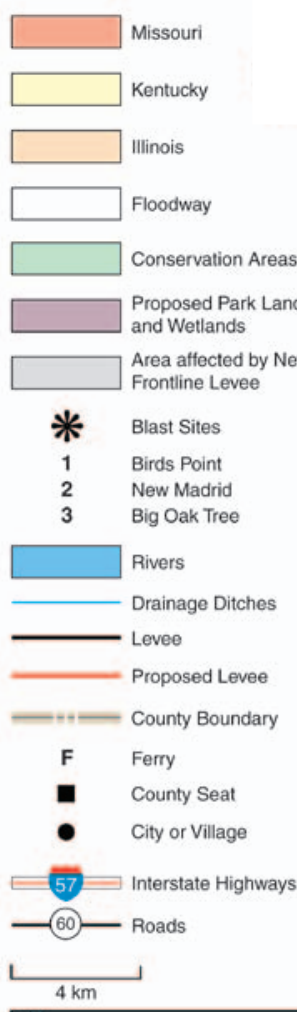

LATITUDE $37^{\circ} 0^{\prime}$

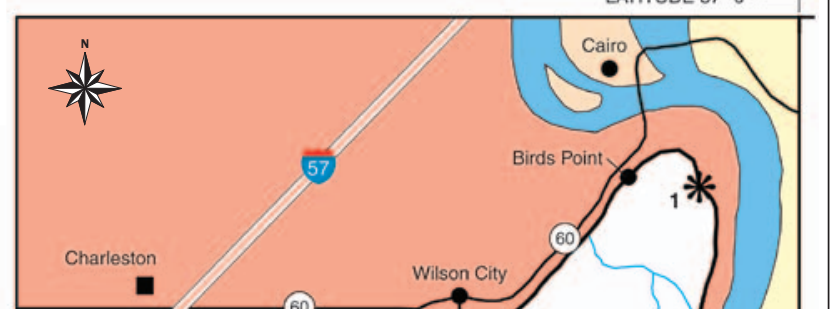

landscapes and rural livelihoods are to be effectively protected.

\section{REVISITING CURRENT LEVEE LOCATIONS AND LAND USES}

The floodway acts as a temporary spillway, taking pressure off the levee system under extreme flood conditions, but sacrifices agricultural production in the year of opening and displaces residents to protect loss of life (Olson and Morton 2012a). If the opening of the floodway were to occur more frequently, the public and private costs of reclamation and restoration of agricultural lands and rural communities will also increase. Although returning the entire floodway to its original alluvial floodplain is likely to not be socially desirable or politically feasible, redesign of the floodway could reduce taxpayer and private costs associated with more frequent flooding events. Landowners in the floodway, levee and drainage districts, and USACE should together explore realignment options that reduce risks and costs.

The floodway is $7.5 \mathrm{~km}$ (5 miles) or less wide at the top and bottom, with a $15 \mathrm{~km}$ (10 miles) wide bulge that follows the Mississippi River. A realignment of the frontline levee away from the Mississippi River (figure 5) and to the west would create a more uniform $7.5 \mathrm{~km}$ (5 mile) width and enlarge the natural floodplain area available to temporarily store floodwaters during high water events. This reengineering of the levee-floodplain relationship would provide a hydrologic and biogeochemical buffer to adaptively respond to the large uncertainties in river management (Park et al. 2012) and could delay or reduce the frequency in which the floodway is opened and exposes agricultural lands within the floodway to increased soil and crop damage. This new frontline levee location would result in approximately 17,600 ha $(44,000 \mathrm{ac})$ being removed from the 53,824 ha $(133,000 \mathrm{ac})$ New Madrid Floodway (figure 5). This recreated floodplain would no longer be protected from Mississippi River flooding by a USACE levee but could remain in agricultural use similar to many of the unleveed bot- 
tomlands of the Ohio River Basin. If the Mississippi River reached flood stage during the growing season, the crop would be lost. Farmers in the area would most likely stop growing winter wheat (planted in fall and harvested during the next summer) in favor of corn and soybeans. Many similar bottomlands in Missouri, Illinois, and Kentucky remain in agricultural use with limited soil damages from flooding events. However, in the Missouri or west side of the Mississippi River, there would likely be less serious soil damage as associated with levee failures (crater lakes, gullies, and sand deposits). These unleveed bottomlands would provide additional water storage capacity during flooding, and the wet soils would help filter pollutants, recharge the water table, capture sediment, and protect adjacent levees from failure. If any parcel or farm in the 17,600 ha $(44,000 \mathrm{ac})$ area were to no longer be used for agriculture, it could be eligible for the USDA Natural Resource Conservation Service wetland reserve program if that program is retained in the 2013 Farm Bill.

A reengineering of the Missouri frontline levee would require hydraulic modeling, including risk and resilience analyses (Park et al. 2012), to ascertain the effects on both sides of the Mississippi, including the Hickman levee and adjacent bottomlands in Kentucky. If the Hickman levee were to fail because of increased pressure, caused by realignment of frontline levee, there could be serious land damages in Kentucky bottomlands, including land scouring, crater lakes, gullies, sand deltas, and sediment deposition. The key concept of this redesign is to mimic more closely the natural floodplain capacity to manage highly variable levels of water and decrease pressure on the levee system under extreme flood conditions. USACE modeling would be valuable in the development of a number of engineered scenarios to evaluate the social, economic, and ecological tradeoffs between relocating the frontline levee further from the Mississippi channel and enlargement of the floodplain to increase natural storage under flood conditions, thereby delaying the opening of the floodway (Park et al. 2012).

A second, more modest redesign would keep the frontline levee in the current location and convert about 1,000 ha $(2,500$ ac) of levee-protected but flood-vulnerable acres of low lying bottomlands from agricultural use to park land and wetlands (figure 5). These are the lands located adjacent to blast site 3 and between the Seven Island Conservation Area and the Big Oak Tree State Park (figure 5). Part of this area could be purchased by the state of Missouri to expand Big Oak Tree State Park. Landowners in the floodway, the Department of Natural Resources, State of Missouri, levee and drainage districts, and USDA Natural Resource Conservation Service should explore the potential land use change options for the area surrounding the Big Oak Tree State Park. Other adjacent low-lying bottomlands may be eligible for a USDA Natural Resource Conservation Service wetland reserve program permanent easement using two 30-year easements or restoration cost share agreement if this program is renewed in the 2013 Farm Bill If purchased with state or federal resources, these wetlands and park lands would provide multiple benefits, retaining current storage capacity at flood stage as well as enhancing local wildlife habitat (figure 6) with ecological and recreational values. This area historically collected the greatest depth of floodwater when the Mississippi River was high and when the floodway was opened, with substantive repair costs following flooding. Returning this 1,000 ha $(2,500 \mathrm{ac})$ area to its original wetland

\section{Figure 6}

The inflow of floodwater created crater lakes and ponds in low wet areas adjacent to Big Oak Tree levee blast site, which resulted in bird nests being built.

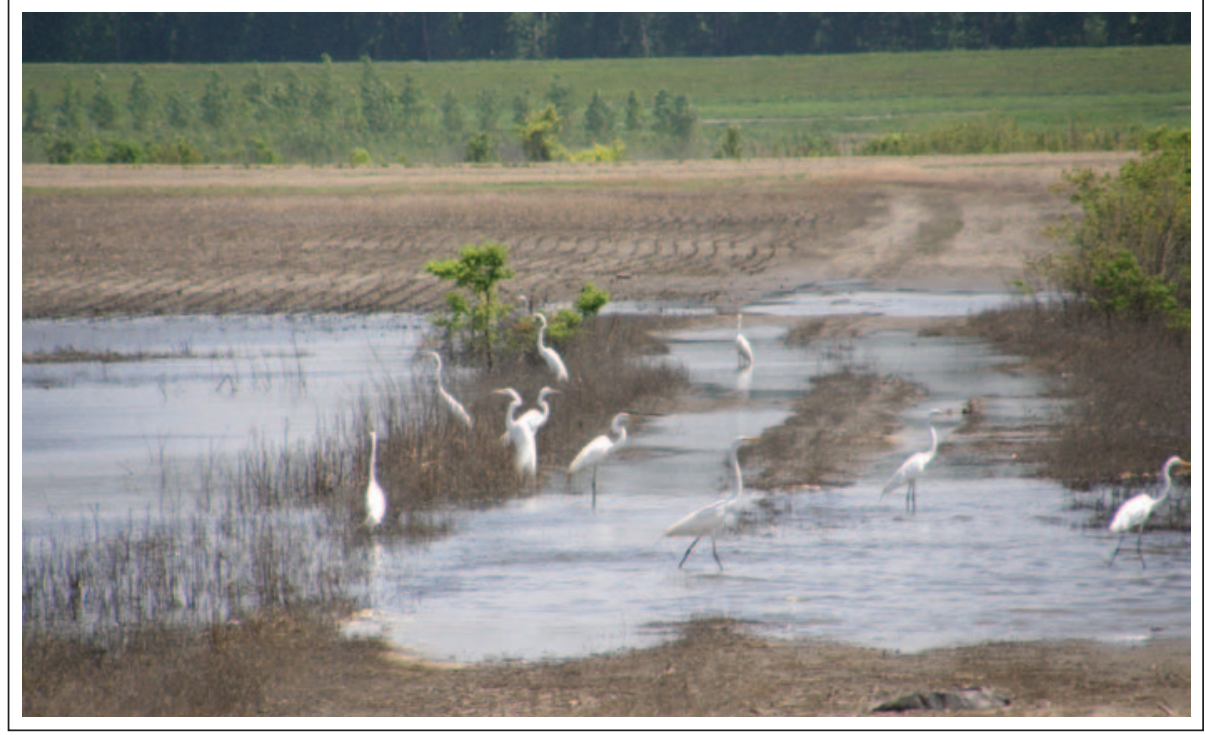

condition would have an economic impact on current agricultural uses. However, the rebuilding of the ecological infrastructure will reduce future flood restoration costs in terms of crop land reclamation, damage to roads, and leveed structure repairs. Any future floodway use, and there will be some, would do less damage to the wetland and park land reserves than would happen with continued agricultural use. This ecosystem is well suited to periodic inundation from heavy rainfall and river flooding.

Both of these options would transform the current land use and be a difficult social and political decision for public agencies and private landowners in the floodway. However, the diverse habitat created by wetlands and park lands could also be an opportunity for the purposeful development of an economic tourism plan to increase the recreational use of the area. The partial return of the Mississippi floodplain to marsh and wetlands offers a compromise, one that attempts to balance the need to protect productive agricultural lands while adapting to changing natural conditions of increased flood pressures on levees and the infrastructure of human settlements.

\section{CONCLUSION}

Changing climate conditions will magnify the risks associated with snow melt, rainfall, runoff patterns, and flooding (Palmer et al. 2009). Shifts in global temperatures 
are likely to have their greatest practical impact via effects on the water cycle, with the amount of water vapor that the atmosphere can hold increasing rapidly with temperature, leading to more extreme rainfall occurrences and flooding (Hansen et al. 2012). As the odds for certain types of weather extremes increase in a warming climate, farmers, rural residents, and public agencies will need both short- and long-term strategies to address reclamation of agricultural lands and restoration of farmsteads and buildings and to put in place adaptive management plans that anticipate future events. Landowners and residents of the Bootheel have experienced a number of transformations to their physical, social, and economic landscape over the last 150 years. A former alluvial plain, this region now has some of the most productive soils in Missouri as well as in the upper Midwest, with high corn, soybean, and wheat yields from systematic investments in technologies and modern management practices. The short-term approach is to expect that this region will continue to be a high-profit agriculture region that should be protected at any cost, with a resistance-adaptation strategy of continual levee repair and reclamation of these lands after a floodway opening. This plan is sound when extreme flooding events are few and far between.

Long-term projections of continued global and upstream warming trends suggest higher probabilities of more frequent weather extremes, with both flooding and drought affecting the region. Under these extreme conditions, the resistance-adaptation model is likely to be inadequate, and a more aggressive resilience-adaptation or transformation approach may be needed (Jackson et al. 2010). Wetlands act like a giant sponge, absorbing rainwater and then slowly releasing it to groundwater and nearby streams (Postel 2011), mediating both potential drought and flooding. Given the rapid pace of change, there is a need for tradeoffs at multiple scales-from field, farm level to landscape and to river basin - in ways that go beyond current short-term land use benefits to create longer term agrobiodiversity with economic and ecological benefits (Jackson et al 2010). A comprehensive plan which complements the leveed engineering infrastructure with recreation of an ecological infrastructure can mitigate flooding and strengthen the effectiveness of well-placed leveed systems (Postel 2011). The cost of moving the frontline levee and returning a portion of the floodway to the Mississippi River alluvial floodplain to increase the storage capacity of water during flood stage or the cost of the government purchasing 1,000 ha $(2,500 \mathrm{ac})$ of the low-lying bottomlands in the floodway will be expensive in the short-term but is likely to reduce long-term public and private payouts for property damage and crop losses. These two alternatives and others should be explored as farmers, local leaders, and state and federal agencies evaluate future scenarios, public resources, and political willingness to address the complex interactions among society, land use decisions, and our water cycle.

\section{ACKNOWLEDGEMENTS}

This project was funded in part by the USDA National Institute of Food and Agriculture Integrated Water Program under agreement 2008-51130-19526, Heartland Regional Water Coordination Initiative.

\section{REFERENCES}

Barry, J.M. 1997. Rising Tide: The Great Mississippi Flood of 1927 and How it Changed America. New York: Simon \& Schuster.

Benning, J., D. Herzmann, C. Ingels, and A. Wilke. 2012. Agriculture and weather variability in the Corn Belt: Bootheel Missouri Bulletin CSCAP00652012-MO. Ames, IA: Iowa State University.

Camillo, C.A. 2012. Divine Providence: The 2011 Flood in Mississippi River and Tributaries Project. Vicksburg, MS: Mississippi River Commission.

Coumou, D., and S. Rahmstorf. 2012. A decade of weather extremes. Nature Climate Change 2:491496, doi:10.1038/nclimate1452.

Gellman, E.S., and J. Roll. 2011. The Gospel of the Working Class. Urbana-Champaign, IL: University of Illinois Press.

Hansen, J., M. Sato, and R. Ruedy. 2012. Perception of climate change. Proceedings of the National Academy of Sciences of the United States of America 109(37):E2415-E2423. http://www.pnas. org/content/109/37/E2415.short.

Jackson, L., M. van Noordwijk, J. Bengtsson, W. Foster, L. Lipper, M. Pulleman, M. Said, J. Snaddon, and R. Vodouhe. 2010. Biodiversity and agricultural sustainability: from assessment to adaptive management. Current Opinion in Environmental Sustainability 2:80-87.

Lowery, B., C. Cox, D. Lemke, P. Nowak, K.R. Olson, and J. Strock. 2009. The 2008 Midwest flooding impact on soil erosion and water quality: Implications for soil erosion control practices.
Journal of Soil and Water Conservation 64(6):166A. doi:10.2489/jswc.64.6.166A.

Moyers, S. 2011a. The death of Pinhook; Community will never return after flooding. Southeast Missourian, June 17. http://www.semissourian. com/story/1737132.html.

Moyers, S. 2011b. Buyouts of Pinhook, Morehouse among topics at round-table discussion with Sen. Blunt. Southeast Missourian, September 2. http:// www.semissourian.com/story/1758866.html.

Olson, K.R., and L.W. Morton. 2012a. The effects of 2011 Ohio and Mississippi River valley flooding on Cairo, Illinois, area. Journal of Soil and Water Conservation 67(2):42A-46A. doi: 10.2489/ jswc.67.2.42A.

Olson, K.R., and L W. Morton. 2012b. The impacts of 2011 induced levee breaches on agricultural lands of Mississippi RiverValley. Journal of Soil and Water Conservation 67(1):5A-10A. doi:10.2489/ jswc.67.1.5A

Olson, K.R., and L W. Morton. 2013. Restoration of 2011 flood damaged Birds Point-New Madrid Floodway. Journal of Soil and Water Conservation 68(1):13A-18A. doi:10.2489/jswc.68.1.13A.

Palmer, M.A., D.P. Lettenmaier, N.L. Poff, S.L. Postel, B. Richter, and R. Warner. 2009. Climate change and river ecosystems: protection and adaptation options. Journal of Environmental Management 44(6):1053-1068.

Park, J., T.P. Seager, P.S.C. Rao, M. Convertino, and I. Linkov. 2012. Integrating risk and resilience approaches to catastrophe management in engineering systems. Risk Analysis. DOI:10.1111/j.1539-6924.2012.01885.x.

Postel, S. 2011. Mississippi floods can be restrained with natural defenses. Water Currents, National Geographic, May 3. http://newswatch. nationalgeographic.com/2011/05/03/mississippifloods-can-be-restrained-with-natural-defenses/.

Schick, A. 2011a. Farmland behind Birds Point levee recovers faster than expected. Columbia Missourian, November 4. http:// www.columbiamissourian.com/a/142312/ farmland-behind-birds-point-levee-recovers-fasterthan-expected/.

Schick, A. 2011b. Mississippi River town of Pinhook struggles to reclaim its community after levee break. Columbia Missourian, December 22. http://www.columbiamissourian.com/a/143923/ mississippi-river-town-of-pinhook-struggles-toreclaim-its-community-after-levee-break/.

USACE (US Army Corps of Engineers). 2010. National Report: Responding to National Water Resources Challenges. Washington, DC: US Army Corps of Engineers Civil Works Directorate. http://www. building-collaboration-for-water.org/Documents/ nationalreport_final.pdf. 